\title{
Women and War Commemoration
}

Building on our examination in Chapter $\mathrm{I} 2$ of the ways in which the Song of Deborah uses war commemoration to negotiate belonging for communities, we turn now to the gender of wartime contributions. A common cultural construction draws a sharp distinction between men, who leave their families to go fight, and women, who wait for their men to return. As will be demonstrated in this chapter, the Song of Deborah and the prose account that precedes it do not partake in the gender polarity that informs the cultural productions of so many societies, modern and ancient. By subverting the status quo and repudiating the conventions of male heroism, they do much the opposite. Moreover, our investigation will reveal that women, although rarely having opportunities to take up arms in defense of their communities, played a central role in war commemoration as "memory makers."

\section{MOTHERS OF SOLDIERS}

At first glance, women appear in ancient discourses on war primarily as objects: victims, trophies, and causa belli. In stereotypical laments, they give voice to suffering, and their bodies, along with those of the children in their care, give graphic expression to the costs of war. A closer examination of the sources, however, discloses the much more complex nature of women's roles and destinies in wartime. Far from being passive objects, they were active agents who consciously and directly shaped how their societies interpreted events on the battlefield.

Women in ancient Mediterranean societies usually did not partake in fighting on the front lines, and societies often went to great lengths to 
evacuate them from the scene of conflict. ${ }^{\mathrm{I}}$ Even so, women contributed to war efforts in a variety of ways - from outfitting and provisioning soldiers to pelting aggressors from atop city walls and even engaging directly in (alternative forms of) combat. ${ }^{2}$ In accounts of the past penned by male writers, their varied contributions have been consigned to oblivion, since memories of women saving the day had the potential to undermine what many considered to be the essential and primary contribution of women to war efforts: bearing male babies and rearing them to be soldiers.

In the book of Genesis, the family of Rebekah sends her off to marry Isaac with the following blessing: "May you, our sister, become thousands of ten thousands, and may your offspring take possession of the gates of their enemies" (Gen. 24:60). ${ }^{3}$ Since states have conventionally fostered procreation, scholars often evaluate the Bible's "natalism" in relation to (pre-state and state) realities during the Iron Age. ${ }^{4}$ To be sure, statesponsored fertility and reproductive politics deserve consideration, yet the biblical corpus was decisively shaped by the experience of defeat and the demise of statehood. The most pressing concern for the scribes who produced this corpus was not to raise a new army, but to survive in a new age, and hence procreation had a new role to play. (Closely tied to procreation is the enculturation/education of future generations in the nation's collective memories and traditions.)

The ways in which progeny and procreation replace a native army and combat is illustrated in a variety of biblical texts. The book of Genesis expresses the point symbolically in the scene of Jacob's and Esau's

I See, e.g., Hdt. 8.36.2, 8.4I.I; Thuc. 2.6.4, 4.I23.4, 5.32.I; Diod. Sic. I3.9I.

${ }^{2}$ See Judg. 9:53-54; Plut. Pyrrh. 34; Paus. I.I3.8; Polyaen. 8.68-69; Thuc. 2.4.2-4, 3.74.I, 5.82.6; Plut. Mor. 245 B-C, $246 \mathrm{D}-247$ A, $248 \mathrm{E}-249 \mathrm{~B}$; Diod. Sic. I 5.83 .3 . See also 2 Sam. 20 for the role a wise woman plays in saving her city during a siege. That women - usually hetairai rather than wives - were present in the war camps of Greek mercenary armies is clear from Xenephon's Anabasis.

3 This wish that the bride would become mother to a powerful fighting force may represent a variation of a traditional blessing. In relation to the Aegean world, see, e.g., Hdt. I.I36 on the honors Persian kings conferred on families with many sons. The information matches evidence from the Persepolis Fortification Tablets showing that mothers who had given birth to sons receive double portions of rations. In Sparta, only those men who had died in combat were commemorated with epitaphs on their tombstones, along with women who had died in childbirth (Plut. Lyc. 27.2 - Latte's emendation).

${ }^{4}$ See, e.g., Carol Meyers, "Procreation, Production and Protection: Male-Female Balance in Early Israel," Journal of the American Academy of Religion, 5I (I983), 569-593; Tikva Frymer-Kensky, "The Atrahasis Epic and Its Significance for Our Understanding of Genesis I-9," Biblical Archaeologist, 40 (I977), I 47-I 55; Ryan Byrne, "Lie Back and Think of Judah: The Reproductive Politics of Pillar Figurines," Near Eastern Archaeology, 68 (2004), I37-I 5 I. 
reunion: the patriarch of Israel is accompanied by his wives and numerous children, while Esau is accompanied by his 400 warriors (Gen. 32-33, discussed in Chapter 2). The book of Ruth imagines "the days of the judges" as an idyllic period, when war was completely absent and the nation was sustained by acts of hesed (loyalty, hospitality, generosity) that result in offspring. The male protagonist Boaz is called a gibbôr hayil; the designation is usually translated as mighty warrior, but here it refers to a man of noble virtue who assumes his social duty, marries a widow, and produces a child with her. The story explicitly plays on the title. When the community blesses Boaz on his marriage with Ruth, it encourages him to act heroically: "May you do a mighty deed of valor (hayil) in Ephrathah, and make a name in Bethlehem" (Ruth 4:II). The expressions "do a mighty deed of valor" and "make a name" here refer not to martial courage or noble death, as they do elsewhere, but to acts of marriage and procreation. $^{5}$

Throughout the biblical corpus, the home competes with the battlefield as the principal stage of national life, and in rethinking the nature of peoplehood, the biblical scribes de-gendered procreation so that it's no longer solely a woman's duty. Infertility becomes an agonistic struggle for men rather than simply the fault of women. The choice to place household stories at the center of Israel's history is a bold statement that power resides in the inner workings of the family and that the project of creating a nation is a collaborative effort.

\section{POLITICAL PERFORMANCES}

Teddy Roosevelt famously compared a woman who "shirks her duty to bear children" to a man who "fears to do his duty in battle when his country calls him." 6 This gender polarity is not unique to modernity. As the French historian Nicole Loraux demonstrated in an important essay, classical Greek sources juxtapose the birthing bed of women with the battlefield of men. ${ }^{7}$ A common motif in classical Greek art is the departure scene, which features a hoplite warrior taking leave of his wife, his son, and often the family dog. To perform aristocratic manhood, the hoplite

${ }^{5}$ On the way biblical texts consistently make procreation, not heroic death, the principal means of making a name, see Wright, "Making a Name."

${ }^{6}$ In my article "Making a Name," I juxtapose this quote with a number of biblical and ancient Near Eastern texts that liken the painful birthing process to battle.

7 Nicole Loraux, "Le lit, la guerre," L’Homme: Revue française d'anthropologie, 2 I (I98I), $37-67$. 
leaves hearth and home - the domain of women - and fights fearlessly alongside other men of the same class. Greco-Roman literature reports many cases of men returning too early from the front lines, only to confront the public scorn of their women. ${ }^{8}$ By appealing to their manhood, the women made sure that their men fulfilled their societal role. ${ }^{9}$

Just as women were expected to send off their men and boys and encourage them to carry out their duties with valor, they performed rituals that involved going out to meet their homecoming heroes. Such performances are well attested in many places and times - from nineteenthcentury German society in which girls robed in white gowns greeted returning soldiers, to the Wankas in sixteenth-century Peru, whose women, according to Francisco's de Toledo's account, "came forth with pitchers of chichi and other things" to confer honor on their triumphant men. ${ }^{\text {IO }}$ In other cases - from Sparta to Achaemenid Persia and pre-Islamic Arabia - women and girls (were) paraded before soldiers on the eve of battle. Their appearance served to stimulate the men to fight and reminded them what they were fighting for. Thus, as the Banū Bakr prepared for war against the Banū Taglib in the early sixth century, two women chanted lyric verses that roused the men to undertake great deeds of valor:

On the day of at-Tahaloq [a war between two tribes], al-Fand az-Zamani, an old man more than a hundred years old, arrived with his two daughters. The first one took off her clothes and started singing to the tribes of Shaiban and Bakr [to encourage them to victory]:

War, war, war, war!

The fire of war is glowing.

How lovely, how lovely, to be with the victorious at dawn!

${ }^{8}$ Plut. Mor. 24I, 244F-245B; Justin I.6.I3-I 5; Hdt. I.37.3, I.82.7, 3.I 34.2; Polyb. 5.83, I 5.30; see the discussion in David Schaps, "The Women of Greece in Wartime," Classical Philology, 77 (I982), I93-2I3.

9 In "Women as Creators of Biblical Genres," Prooftexts, 8 (I988) I-33, at 3, S. D. Goiten calls attention to songs of mockery and goading in Arab culture: "When a poet came to lament over her brother or some other fallen hero of the tribe, she reproached her fellow tribesmen in the harshest terms for not preventing his death or for not hurrying to seek vengeance for him. Mockery of the conquered enemy and joy at his misfortune are also found, but perhaps less than goading of her own tribe to go out to war. The poetess' clever mockery was a weapon which the ancient Arabs feared more than the edge of the sword."

ro The color symbolized the purity of the women that the victorious troops had protected; see Ute Frevert, Die kasernierte Nation: Militärdienst und Zivilgesellschaft in Deutschland (Munich: Beck, 200I). On the Wankas culture and de Toledo's account, see Timothy Earle, How Chiefs Come to Power (Stanford: Stanford University Press, I997), II 5 . 
The second one also took off her clothes and sang:

We are the daughters of Tariq.

We walk on carpets.

If you fight, we'll embrace you.

And prepare beds for you

But if you desert, we'll abandon you. ${ }^{\text {II }}$

Arabian women played drums in battle to encourage the warriors to victory, as well as when performing laments (marthiya or nawh) for heroes. Thus, Mohammad's enemy, a woman named Hind bin Utba, used drums when commemorating the war dead with songs and lamentation. ${ }^{\mathrm{I2}}$

Closer to the biblical period, archeologists uncovered at Achziv ( $5 \mathrm{~km}$ north of Acco) what became known as the Tomb of the Horsemen. Deposited in the grave were figurines of women drummers alongside various other objects, such as figurines of horsemen. As Sarit Paz notes in Drums, Women, and Goddesses, it's conceivable that "the juxtaposition of the women drummers and horsemen denotes the 'victory song' tradition of women who go forth singing, drumming, and dancing to greet the warriors returning from battle." ${ }^{13}$

This "victory song" tradition to which Paz refers is well attested in biblical literature. Thus, the daughter of the triumphant Jephthah comes out to welcome him, at his homecoming, with dance and tuppim (Judg. I I:34). The latter are likely frame drums, similar to the Greek tympanum or the Arabic $d u f f .{ }^{\mathrm{I}}$ Women do the same for Saul and David when they return from their battles with the Philistines (I Sam. I 8:6-7), playing tuppim and other instruments. Likewise, Miriam leads the women of Israel with tuppim and dancing after the victory at the Red Sea (Exod. I 5:20).

Such performances had extraordinary political potential. For example, in the story of Saul and David, the praise chanted by the women has

${ }^{I I}$ From Ibn al-Kalbi (d. 8I9), as quoted in Veronica Doubleday, "The Frame Drum in the Middle East: Women, Musical Instruments and Power," Ethnomusicology, 43 (I999), IOI-I34, at I 29 .

${ }^{12}$ Doubleday, "Frame Drum," I09.

${ }^{3}$ Sarit Paz, Drums, Women, and Goddesses: Drumming and Gender in Iron Age II Israel (Fribourg: Academic Press, 2007), I2I.

${ }^{14}$ See Carol Meyers, "The Drum-Dance-Song Ensemble: Women's Performance in Biblical Israel" in Kimberley Marshall (ed.), Rediscovering the Muses: Women's Musical Traditions (Boston: Northeastern University Press, I993), 49-67, 234-238; Miriam Tadmor, "Realism and Convention in the Depiction of Ancient Drummers" in Yairah Amit et al. (eds.), Essays on Ancient Israel in Its Near Eastern Context (Winona Lake: Eisenbrauns, 2006), 32I-338. 
a subversive ring to it: "Saul has slain his thousands, and David his myriads." The lyrics seem harmless enough, since they extol the deeds of the reigning king. However, by paying tribute to an upstart and ambitious warrior and singing his name in tandem with the king's, the celebration paves the way for that upstart to seize the throne. When Saul hears the words of their song, he furiously concedes that: "the only thing he has yet to gain is the kingdom itself!" (I Sam. I 8:8-9). The performance by these women has an impact far beyond Israel's borders, and the Philistines cite their song twice as evidence of David's political ambitions (I Sam. 2I:I2, 29:5).

In the case of Jephthah, his rule over Gilead depends on his success in battle. Hence, he utters a vow to sacrifice whoever comes out first to meet him if he returns triumphantly. Since he has only one daughter, it was likely that either she or his wife would be the sacrificial victim. When he returns from vanquishing the enemy, it's his daughter who comes out to greet him, and the text suggests that she does so knowingly:

On seeing her, Jephthah rent his clothes and said, "Alas, my daughter! You have brought me very low. You have become my troubler! For I have opened my mouth [i.e., made a vow] to Yhwh and I cannot retract." "Father," she said, "you have opened your mouth to Yhwh. Therefore, do to me as you have spoken now that Yhwh has brought victory for you against your enemies, the Ammonites.” Judg. I I:35-36

The song that Miriam sings at the exodus is equally political inasmuch as it pays homage to Yhwh alone without mentioning Moses or any human warrior in the nation's ranks:

Then the prophet Miriam, Aaron's sister, took a drum in her hand, and all the women went out after her with drums and with dancing. And Miriam chanted to them: "Sing to Yhwh, for he is truly exalted. Horse and chariot he has hurled into the sea." Exod. I 5:20-2I

It is their song that determines how that battle is commemorated, and it may have directly influenced the composition of the longer Song of the Sea (compare Exod. I 5:2 I with Exod. I 5:I).

In these and other texts, we witness how the messages encoded in women's songs and celebrations had the potential to sway public opinion far and wide. Victory is first and foremost a performance, and the song and dance of women determined to a considerable extent how triumphs and defeats were remembered. They might deflect honor from the reigning king by praising him alongside a figure who has his eye on the throne, or 
they might deflect honor from men altogether by focusing attention on the nation's deity. ${ }^{\mathrm{I5}}$

\section{BETWEEN BED AND BATTLEFIELD}

Our accounts of Deborah and Jael presuppose these conventional wartime roles. Like Arabian prebattle rituals, the poetic version exhorts Deborah to break out in song at the same time as it enjoins Barak to take captives (Judg. 5:I2). The preceding prose story depicts Jael going out to meet Sisera, the enemy general. Her behavior follows the pattern of women's postbattle performances - but with a dramatic twist: Sisera is not a returning hero but the leader of Israel's enemy fleeing to save his life. Jael entices him into her tent under the pretense of hospitality; once he enters her domain, she slays him with cunning and stealth. ${ }^{16}$ Having made a battlefield out of her domestic confinement, she then goes out again to meet Israel's returning warrior, Barak. Yet instead of hailing him as the champion, she invites him to come into her tent and see the man whom he was seeking and whom she has slain. ${ }^{17}$

In many photos and artistic renderings of Middle Eastern aristocracy, women often lie reposed on divans. In contrast, men stand proudly or sit mounted on their steeds, parading their weapons prominently. To advertise confidence, a man might depart from these expectations by posing in a recumbent posture, especially if it's in the company of women. Such is how the Assyrian king Ashurbanipal is portrayed in an impressive palace

I5 Psalm 68 similarly refers to the women who bear tidings of Yhwh's victory as a great "army" or "host." In keeping with its anti-monarchic thrust, the book of Joshua, which depicts a military hero slaying kings right and left, does not depict women honoring him with hymns or rituals of triumph. Nowhere do we read that the women went out with their drums to greet Joshua and his warriors when they returned from battle.

${ }^{16}$ On the role of hospitality in this account, see Victor Matthews, "Hospitality and Hostility in Judges 4," Biblical Theology Bulletin, 2I (I99I), I3-2I; as well as, most recently, Anne Katrine de Hemmer Gudme, "Death at the Hand of a Woman: Hospitality and Gender in the Hebrew Bible" in Stephanie Lynn Budin (ed.), Gender and Methodology in the Ancient Near East (Barcelona: Universitat de Barcelona Edicions, 2019), 23-33; Gudme, "Invitation to Murder: Hospitality and Violence in the Hebrew Bible," Studia Theologica - Nordic Journal of Theology, 73 (2019), 89-108. Gudme offers a new interpretation of Jael, Rahab, and others that considers hospitality in the Hebrew Bible as a distinctively male prerogative.

${ }^{17}$ If the song is secondarily ascribed to Barak, as many scholars claim (the line begins "And she sang"), it may have been to show that he finally realizes and celebrates how Yhwh brings victory through the hands of women (Judg. 4:9). See Steven Weitzman, Song and Story: The History of a Literary Convention in Ancient Israel (Bloomington: Indiana University Press, I997), 35-36. 
relief (ca. 645 BCE), which depicts the king reclining on a couch in his garden and drinking with his wife. His weapons rest behind him, and the head of the enemy king dangles from a tree. The passivity of the scene has a theological quality: if the king can rest at home with the queen, it's because his deity, the goddess Ishtar, leads his army against the enemy for him - "You stay here in your place, eat bread, drink wine, play music, and praise my godhead, while I go there to complete the job, and to fulfill your heart's desire." 8

Adventuresome valor is extolled in the Erra Epic, one of the most widely circulated texts in Mesopotamia during the first millennium. A portion of the epic, called "The Warrior's Manifesto," beckons the hero to arise and partake in the "feast" of the battlefield, instead of "sitting" (wašăbum) like an old man in the city, like a little infant in the house, or like the timorous who "eat the bread of women" (I:46-49; cf. the use of $y$-š-b in Judg. 5 and Num. 32 ).

To cite an example from personal correspondence, Shamshi-Adad, a king from the Old Assyrian Empire, wrote to his son in ca. I776 BCE admonishing him to withdraw from the company of women in order to go out and conquer:

Here your brother won a victory, but there you lie among women! Now, when you march with your army to Qatna, be a man. As your brother has established a great name, you also in your region establish a great name. (ARM I:69)

The expression "establish a great name" refers here not only to feats on the battlefield but also to the act of setting up a victory monument bearing the name of the ruler.

Biblical texts, too, present the battlefield and the bed as antithetically gendered spaces. Thus, the David-Bathsheba story from the book of Samuel has the king staying back in Jerusalem and sleeping with the wife of one of his soldiers while the nation is away engaged in a military campaign.

Defying this spatial polarity, Jael transforms her bed into a battleground. ${ }^{19}$ In the prose version of the account, Jael goes out of her tent to meet Sisera and lures him into her tent: "Turn aside, my lord, turn aside to me; have no fear." Later, displaying maternal

${ }^{18}$ See the discussion in Jacob L. Wright, "Commensal Politics in Ancient Western Asia: The Background to Nehemiah's Feasting (Part I)," Zeitschrift für die alttestamentliche Wissenschaft, I 22 (2010): 2I 2-233, at 230-3I.

I9 In this respect, she resembles Delilah, as underscored by Milton; see the following section of this chapter. 
hospitality, she covers him with a blanket. When he asks for water, she serves him milk. ${ }^{20} \mathrm{He}$ orders her to stand at the entrance lest a man come looking for him. When he falls fast asleep, confident that he has found a secure place to rest, she drives a peg into his temple, pinning him to the ground. The song makes Jael's deed even more daring and Tarantinoesque. Instead of waiting for him to sleep, she straightaway crushes his skull with a hammer so that he topples over and then falls dead between her legs. Meanwhile, Sisera's mother waits passively and patiently at her home for her son to return triumphantly as a warrior from battle. In one of the finest literary flourishes in the biblical corpus, we overhear this woman reassuring herself in front of her ladies-in-waiting, as she gazes from her window, that her son is delayed in his return because he was busy collecting and dividing up the spoils, which include "a damsel [lit. a womb] or two for each man." ${ }^{21}$ Little can she imagine, as the reader knows, that one of those damsels had assassinated her warrior-son.

For many contemporary readers, Jael's tent peg is a phallic symbol. When she plunges the object into Sisera, she murders the male warrior with a kind of violent sexual penetration. ${ }^{22}$ Yet while the account is undeniably suggestive in this direction, and highlights Jael's seductive ploy, one should not lose sight of the more basic manner in which it depicts Jael seizing quotidian objects to achieve something that the male warrior Barak could not. Her creativity reminds us of the women in the Aegean world who hurled house tiles upon invading armies, or the unnamed figure in Judges 9 who launches a millstone - simultaneously the implement and symbol of her role as a woman - from atop a tower, crushing the skull of Abimelech, Israel's first king. Moreover, the tent peg, hammer, and milk symbolize Jael's identities not only as a woman but also as a tent-dwelling nomad and a member of an ethnic group known for animal herding and metalworking. (In Chapter I4, we consider aspects of her ethnic identity.)

20 The milk may signify Jael's attempt to make her guest drowsy, as suggested by the sixteenth-century commentator Ibn Zimra (Radbaz). Rashi argued that it was her way of testing Sisera to see if he was fully conscious. The song adds that she served the milk in the finest vessel, underscoring thereby her attempt to win his confidence through her hospitality (but cf. mayim 'addîrim in Exod. I 5:10).

${ }^{21}$ On the term, see the Mesha Stele, lines I6-I7.

22 This interpretation is found, or at least intimated, already in rabbinic writings. The Ehud story in Judges 3:I2-30 may have served as the template for the Jael episode; their common features are frequently noted in studies and commentaries. 
The book of Judith from the Hellenistic period draws directly on our story and drives its gender reversal even further. It portrays a woman achieving a name and honor for herself $(\mathrm{I} 6: 2 \mathrm{I}-23)$ by performing a feat of martial valor. Instead of enticing the victim into her tent, she abandons her frightful countrymen in order to penetrate the enemy camp. Once she decapitates the enemy general, she marches with his head, as David did with that of his Philistine competitor. Just as the dancing women had gone out to meet returning male heroes, so now they go out to welcome this triumphant woman. Traditional roles are transformed as "all the men of Israel in their armor, bearing garlands and with songs on their lips," join the women's procession ( $\left.15: \mathrm{I}_{2}-\mathrm{I}_{3}\right)$.

\section{MEMORY AS A MORAL IMPERATIVE}

Societies rarely recognize the critical role women have played in war commemoration, just as they rarely commemorate women's direct contributions to war efforts. ${ }^{23}$ The problem persists to the present. Thus, more than a thousand female aviators flew some sixty million miles in the Army's aircraft during World War II, yet because these members of the Women Airforce Service Pilots (WASPs) were not considered real military pilots, no flags were draped over the coffins of the thirty-eight members who died in the line of duty. After the war ended, the surviving members of the unit paid their own bus fare home, and for decades thereafter they fought an arduous battle for recognition. In I977, they were finally granted official veteran status. More than thirty years later, in 2009, the remaining members received a prestigious award; it was, however, the Congressional Gold Medal - a civilian honor.

A moral failure to commemorate women's contributions cannot be charged against the book of Judges. As we've seen, the scribes who composed the account diminished the heroic contributions of men by assigning credit for the greatest martial feats to "a mother in Israel" and to a woman who represents a marginal group in their society. Nothing is said about the direct progeny of these two women; their attention is directed elsewhere. As the book's ideal leader, Deborah exerts authority over all others in her society. She beckons the warrior Barak, issues his

${ }^{23}$ Ben Sira includes a lengthy encomium on the great deeds of men (44:I). For the late Second Temple period, this text witnesses to a possible formal, ritual setting in which the names of national heroes and warriors were commemorated with the help of transmitted eulogies. 
battle orders, and thereby severs his military role from the right to govern. Instead of staying behind the front lines, she accompanies him into battle while warning him that another woman, Jael, would secure the glory he sought. ${ }^{24}$

Addressing the issue of collective amnesia most directly, the story of Jephthah, several chapters later, portrays "the daughters of Israel" coming together every year for four days to "recount" (letannôt) the deeds of his brave daughter, who had not produced a child and who, without their efforts, would be consigned to oblivion (Judg. I I:40). It is this imagined festival that preserves this nameless woman's memory; meanwhile, what preserves Jephthah's memory is an account that excoriates his hypermasculine obsession with his own name-making.

Delilah is yet another woman from the book of Judges, and Milton's Samson Agonistes (I67I) has this figure expressing a desire to be named among the famed for eschewing "wedlock-bands" and saving her country from an enemy predator:
But in my countrey where I most desire, In Ecron, Gaza, Asdod, and in Gath I shall be nam'd among the famousest Of Women, sung at solemn festivals, Living and dead recorded, who to save Her countrey from a fierce destroyer, chose Above the faith of wedlock-bands, my tomb With odours visited and annual flowers. Not less renown'd then in Mount Ephraim, Jael, who with inhospitable guile Smote Sisera sleeping through the Temples nail'd. ${ }^{25}$

In wishing to be "sung at solemn festivals" and to have her grave visited in annual celebrations, Delilah not only reminds us of Jephthah and his nameless daughter; she also covets the fame that Jael enjoyed in Mount Ephraim for demonstrating "inhospitable guile" to a sleeping enemy. Exercising midrashic license, Milton joins here the architects of biblical memory in an effort to restrain the male ego by celebrating, with the help of graphic and shocking images, the

${ }^{24}$ As noted in Chapter Io, the account features both the king Jabin (who hardly plays a role in the account) and Sisera, his general, in order to place Deborah on a par with this ruler and demote Barak to the corresponding rank of her general. On the other ways in which the book of Judges severs the conventional connection between martial heroism and political authority, see my article "Military Valor and Kingship."

25 Lines 980-995. 
(martial) feats women are capable of performing to make a name for themselves. ${ }^{26}$

${ }^{26}$ On this theme in biblical literature, see my essay "Making a Name." Milton's view of women in Paradise Lost stands in stark contrast to this work; see Barbara K. Lewalski, "Milton on Women - Yet Once More," Milton Studies, 6 (I975), 3-20; John B. Mason, "Multiple Perspectives in Samson Agonistes: Critical Attitudes Toward Dalila," Milton Studies, Io (1997), 23-34. 